\title{
The Importance of Collaboration and Competition Within and Outside the OECD
}

\author{
Ian Jackson ${ }^{1} \&$ John McManus ${ }^{1}$ \\ ${ }^{1}$ Faculty of Business, Education and Law, Staffordshire University, United Kingdom \\ Correspondence: John McManus, Faculty of Business, Education and Law, Department of Strategy and \\ Economics, Staffordshire University, United Kingdom. E-mail: professorrmcmanus@gmail.com
}

Received: June 6, 2016

Accepted: June18, 2016

Online Published: August 10, 2016

doi:10.5539/ijbm.v11n9p13

URL: http://dx.doi.org/10.5539/ijbm.v11n9p13

\begin{abstract}
The purpose of this paper is to address the role of the OECD in the global marketplace. The paper highlights some current trends in the global market and the changing role of the OECD. In this context, the authors discuss various perspectives on the role of OECD in a globalized world. The authors focus on recent debates on the state of the global economy and the changing position of the OECD in the world market. The authors apply a conceptual approach combined with analyses of data and secondary material. The authors also put forward an argument for investigating what determines competition within and outside the OECD. In this context, creating markets within a global economy requires considerable stimulus on the part of national governments. This necessitates national governments working together in partnership with national and global firms to reduced bureaucracy and increase transparency to boost trade in a cost effective manner. This is seen by some economists to be a prerequisite to future competitiveness. Finally, the authors seek to demonstrate how leading countries within the OECD are building innovative capability to master the challenges and opportunities that the new emerging economies present (such as Brazil).
\end{abstract}

Keywords: globalisation, economic development, emerging economies, alliances

\section{Introduction}

The OECD was set up under a convention signed in 1960, which provides that the OECD shall promote policies designed "to achieve the highest sustainable economic growth and employment and a rising standard of living in Member countries (Table 1) while maintaining financial stability. For much of its history, the OECD was considered to be a "temple of growth" or the "growth conscience" of its members (Schmelzer, 2012). A recognized strength of the OECD is its cross-sector analytical capability and multi-policy committee machinery which allows it to set out forward-looking policy options (Gass, 2002). Since 1960, the OECD has at various points attempted to consider long-term economic trends. An OECD initiative called Interfutures was launched in the late 1970s to establish a wide-ranging framework of growing interdependence to promote long-term growth and better management of the world economic system. Since 2003, the OECD has contributed to discussions on the major economic risks of the 21 st century through studies focusing on the effectiveness and openness of innovation and market competitiveness.

\section{Method and Approach}

Arguably, within many OECD member countries characteristics of economic development such as innovation have had positive effects on the dynamics of growth and domination within the markets. In this context, we seek to identify the key strengths and weaknesses of the OECD and review some of the new emerging economies as the most significant partners for OECD countries to work with in the coming decades. The analysis presented in this paper is supported by a review of contemporary literature in emerging markets and strategic management. The first part of the paper, (3.1 to 3.4) describes the evolution of the OECD and the key elements of success of new the new emerging economies such as Brazil and the pressures that they exert on the OECD economies. The second part of the paper, (3.5 and 3.6) examines the national competitiveness and policy regulation in response to changing markets within the OECD and the newer emerging economies. The key investment sectors of the Central and Eastern Europe and Commonwealth of Independent States whose activities affect the market are also discussed, with a brief summary of the trends and outlook for their impacts, followed by an assessment of the options that could be applied such as free trade agreements to reduce negative impacts on OECD countries. 


\section{Literature Analysis and Discussion}

\subsection{Developments within the OECD}

From a political, economic, social and technological perspective, globalisation touches everything a firm does. Economic systems in the twentieth century were largely characterised by the influence and development of Taylorism (Ohmae, 1995; Botten \& McManus, 1999; Peaucelle, 2000; Scholte, 2000), but it is post-Taylorist, flexible forms of entrepreneurial organisations that drive and shape globalisation today, especially in an increasingly digital-orientated age. It could be argued that the current wave of globalisation coincided with the entrepreneurial sea change of the early 1980s, and the emergence of post-Taylorist organisations whose formidable competitive strength constitutes the principal microeconomic force now driving globalisation (Botten \& McManus, 1999). The movement of tangible and especially intangible forms of capital, finance and technology, as well as changing nature the ownership or control of assets, has become the most prominent feature of globalisation, while national and corporate strategies and behaviour drive it. This is emphasised by the recent Transatlantic Trade and Investment Partnership (TTIP) between the US and EU where TTIP is expected to benefit the rest of the world, with additional gains that could generate $£ 85$ billion worldwide, whilst at the same time strengthening and protecting markets within the OECD membership.

Rapid and pervasive technological change as well as alterations in government policies and market deregulation have visibly shaped and given impulse to a new wave of globalisation since the late 1970s (Oman, 1995). Equally important is far-reaching change in "industrial organisation", that is the way activity is organised within firms and the way firms co-operate and compete. This change blurs the very distinction between industry and services in addition it alters the notion of the firm and the market (Williamson, 1975). More than any other, it disrupts entrenched markets and alters the "rules of the game" across many of the world's markets (Cowden \& Alhorr, 2013). Within the OECD many of these new game rules have focused on deregulation and global competition in all major markets (telecommunications, banking, financial services, internet services, et cetera;) between competitors in almost all major OECD countries, the increasing multinational origin of the inputs to the production of goods and services, and the growing intra-industry role of world trade driven by the "taste for variety" (Dixit \& Stiglitz, 1975) and the interdependent role of the various elements of globalisation are all contributing to a transformation of markets within the global economy.

\subsection{Outward Market Orientation}

Responsiveness to global and market conditions within and outside the OECD is seen as the model to success in the market. Stalk and Hout (1990) claim that innovation was the fundamental advantage behind Japan's success in a number of highly competitive markets such as energy, motor vehicles and consumer electronics, enabling them to increase the variety of technological sophistication of their products and services. In the contemporary global business environment the advantage of using innovation based strategies (that is new business models and system approaches to strategy formulation) are the benfits that accrue from market synchronisation in that products and services can be brought to market quickly, establishing a valuable lead over competitors (McManus, White, \& Botten, 2009). To illustrate the above points many of Japan's innovative firms are pursuing a similar approach in high technology areas such as robotics and airospace. One of Japan's largest companies Toyota is investing millions in battery and petrol driven hybrid vehicles as a stepping stone to fuel efficient cars and has already begun testing fuel cell vehicles in America (Rudell, 2004).

One emerging economy Brazil is making its presence felt in high technology markets such as aerospace and telecommunications. The importance of vision in global success cannot be underestimated. Firms like Embraer which have become one of the largest aircraft manufacturers in the world by focusing on specific market segments with high growth potential in commercial, defence, and executive aviation. Embraer who employ around 20,000 people ( $86 \%$ of which are located in Brazil) have managed to build a significant market presence by providing competitive and innovative solutions with high technological standards and lean production methods and strategies focused on time compression to market. The use of this model allows Embraer to reduce the development time of any new aircraft. Customers can follow the aircraft development steps and are able to check the internal configuration, as well as define the overall scheme in an exact way (AE\&AT, 2001). Although Embraer benefited from government, intervention in its fledgling years not all industries have been so fortunate. Brazil's macroeconomic national policies that are sometimes dissociated from public efforts to promote market growth have hindered some of Brazil's other high technology industries (Krugman, 2014). Brazil's high value of the local currency in relation to the American dollar for most of the past decade, combined with continuing high interest rates diverting investment from production and export, have contributed to reduce many local industry's external competitiveness. 


\subsection{New Wave Expansion}

Few would argue the influence technology as had on markets and the global economy (McManus, Li, \& Moitra, 2007; Harmon, 2012). Rapid expansion in business-to-business and business-to-commerce has been breathtaking in the last decade. Much of the current expansion in world trade is being fuelled by a renaissance in entrepreneurial activity and innovation both within the OECD and those countries outside it. In the past entrepreneurs were disadvantaged by the buying and bargaining power of the multinational firms. To some extent this situation has been diluted as bigger firms hook-up with smaller knowledge based businesses to leverage economies of scale once the domain of the multinational Taylorist producers (Botten \& McManus, 1999). There is much evidence of this practice recently in the UK pharmaceutical industries often clustered around the Cambridge Science Parks in the south-east of England (Hsuan \& Mahnke, 2011).

Global world competitiveness depends increasingly on the coordination of, and synergy generated between, a broad range of specialised industrial, financial, technological, commercial, and cultural skills which can be located anywhere around the world. What this translates into is rationalisation. Production is being rationalised globally, with firms combining the factors, features and skills of various locations in the process of competing markets (Hatzichronoglou, 1996; McManus, Li, \& Moitra, 2007). There are three major dimensions of change involved: increasing national (location) specialisation; increased international fracturing of value chains or chains of production and greater line-item by line-item trade imbalances; and substantial structural dislocation in local, regional and national economies, and a consequent need for substantial structural adjustment. McManus and Botten (2006) point out that faced with these multiple challenges usually requiring action going beyond the capabilities of any single firm, and even those of ad-hoc co-operation between firms and governments, it is important to (still) have a comprehensive concept of the goal of competitiveness so as to orientate the search for global competitiveness in different markets (Tomlinson \& Jackson, 2011).

\subsection{Cooperation and National Competitiveness}

Economic observers believe that promoting trade, competitiveness and economic integration within the European Union has been and continues to be an uphill struggle (Stiglitz, Report of 2010). While increasing economic interdependence is widely recognised, there is no general agreement on the shape that the international economic order is to take in response to the pressures that interdependence generates. From a conceptual point of view Alexis and Pench (1997) identify two different approaches to deal with increasing economic interdependence, shallow integration and deep integration. Shallow integration involves increasing market access consistent with the maintenance of national sovereignty regarding non-border policies. In such a world, countries tend to refrain from incrimination of foreign products or producers, but retain their freedom of action in other areas and compete on the basis of their natural endowment regulatory regimes. Deep integration is where governments are willing to further integrate their economies through liberalisation but also to increasingly treat domestic regulatory policies and international interactions between policy areas as matters for international coordination to provide for corresponding delegation of powers. Overall, the international economic order remains closer to the first than to the second model, that is, shallow integration predominates, though not without significant gaps, and the most binding international disciplines are those seeking to improve market access and reduce discrimination.

Researchers into competitiveness and globalisation argue that the economic centre of gravity is shifting from those nation states in the West to those in the East and southern hemispheres (Porter, 1998; Floyd \& McManus, 2009). Countries such as China, Singapore, Hong Kong, Thailand, Indonesia and South Korea have secured and strengthened their competitive positions in many market sectors (software, financial services, electronics, education, et cetera). Not surprisingly, the embrace of capitalism and market mechanisms has allowed the new developing economies of the world to start catching up with the advanced economies (and in a relatively short period of time). The convergence of telecommunications and information technology has made possible a global command and control structure for transnational's, building a global assembly line for goods and services. In building this global assembly line, a single management framework has emerged and this framework assimilates many of the management innovations and disciplines and experiences of the last twenty years based in part on the make-or-buy paradigm of Transaction Costs (Williamson, 1985). Many of the West's Asian competitors have enhanced new ideas and technology with spectacular success. For example, in contrast with the US and Japan, which lead the world in technology and capital intensive goods, China is a producer of labour intensive or resource intensive goods. With machinery and electronics, accounting for $36 \%$, of its manufacturing output (including machine tools, special-purpose equipment, transportation tools, electronic communications equipment, instruments and etc (Investing in China, 2005). For over a decade, developing countries (such as China, India, Malaysia and Indonesia) have been growing much faster than the developed countries. The developing world's 
share of global GDP is over 45 percent in 2011 (and expected to be 60 percent by 2030). Asia's share of the global economy in purchasing power parity terms has risen steadily from 7 percent in 1980 to 21 percent in 2008 . Asia's stock markets now account for 32 percent of global market capitalization (ahead of the United States at 30 percent and Europe at 25 percent) (Zoellick, 2010).

\subsection{National Competitiveness Operating within the OECD}

According to McManus, Li, and Moitra (2007) the view of globalisation requires that management innovations be thought of as mechanisms to drive up market and customer value (through global value chains, interfirm cooperation, technology tie-ups and international finance). The increasing global competitiveness and importance of countries operating in the OECD (Organisation for Economic Cooperation and Development is reflected in the growing number of European firms that have been merged or acquired in the last ten years. Some of the largest mergers and acquisitions within the OECD in recent years have been: the record-breaking merger of British Telecom and MCI telecommunications); Daimler Benz and Chrysler (automobiles); Dupont and Herberts (chemicals and paints); Alcatel and Motorola (phone and telecommunications equipment), and Alcatel's subsequent acquisition of DSC Communications; the acquisition of MCA by Seagram (entertainment); and the purchase of Marion Merrel Dow by Hoeschst (pharmaceuticals).

Table 1. Membership OECD

\begin{tabular}{llll}
\hline Australia & Germany & Luxembourg & Portugal \\
\hline Austria & Greece & Mexico & Spain \\
Belgium & Hungary & The Netherlands & Sweden \\
Canada & Iceland & New Zealand & Switzerland \\
Czech Republic & Ireland & Norway & Turkey \\
Denmark & Italy & Poland & United Kingdom \\
Finland & Republic of Korea & Luxembourg & United States \\
France & Japan & Mexico & \\
\hline
\end{tabular}

The expanding field of mergers and acquisitions within the OECD illustrates the growing interconnections of a single world capital class. According to Robinson and Harris (2000), the reality of capital as a totality of competing individual capitals and their concrete existence as a class relation within specific spatial confines determined geographically as nation-states worked against a transnational, or supranational, unifying trend in the development of world capitalism. The liberation of capital from such spatial barriers brought about by new technologies, the worldwide reorganisation of production, and the lifting of nation-state constraints on the operation of the global market imply that the locus of class and group relations in the current period is not the nation-state. Currently the expansion of direct foreign investment, cross national mergers, strategic alliances, the interpenetration of capital, and interlocking directorates that are transnational are all examples.

Firms operating within the OECD have sought to increase their presence and investment funds within CEE/CIS regions (Central and Eastern Europe and Commonwealth of Independent States). Companies targeted operate in manufacturing financial services, energy and utilities industries, as well as the food and beverage sector. A report by Price-Waterhouse Coopers highlights significant activity regarding market opportunities and mergers and acquisitions within CEE/CIS (Table 2). For example, Russia's new found status as a global market provider of energy to OECD countries is attracting a significant amount of inward investment add to this the domestic money that was parked offshore which is now coming back into the economy and being used for capital investment in non-energy sectors like construction, textiles, heavy machinery, food processing, microbiology, pulp and paper and fertilizers in the last two years. To judge from experience the flow of Russian investment back into the country indicates that Russian managers firmly believe in their country's ability to adapt to new economic realities, even if the price of oil may be uncertain in the future. Two factors helped the Russia; namely higher oil prices and devalued rubble that made domestic companies more competitive. For the longer term, Russia cannot rely exclusively on energy resource revenues, but must focus on deep institutional reform of its economy. Russia has made significant strides in the last year but, the country's debt level remains relatively high, and much depends on whether Russia is able to adapt to a slowing world economy and variable oil prices. 
Table 2. Top 10 mergers and acquisitions in the CEE/CIS regions

\begin{tabular}{|c|c|c|c|c|c|}
\hline Rank & Investor & Target & $\begin{array}{l}\text { Investor } \\
\text { Country }\end{array}$ & $\begin{array}{l}\text { Target } \\
\text { Country }\end{array}$ & $\begin{array}{l}\text { Approx Value } \\
\text { (USD m) }\end{array}$ \\
\hline 1 & Gazprom OAO & Siberian Oil Co OAD & $\begin{array}{l}\text { Russian } \\
\text { Federation }\end{array}$ & $\begin{array}{l}\text { Russian } \\
\text { Federation }\end{array}$ & 13,091 \\
\hline 2 & Vodafone & Mobilfon SA & $\begin{array}{l}\text { United } \\
\text { Kingdom }\end{array}$ & Romania & 2,500 \\
\hline 3 & Telekom Austria AG & MobilTel EAD & Austria & Bulgaria & 1,969 \\
\hline 4 & Investor Group & Milkhailovsky GOK OAO & $\begin{array}{l}\text { Russian } \\
\text { Federation }\end{array}$ & $\begin{array}{l}\text { Russian } \\
\text { Federation }\end{array}$ & 1,650 \\
\hline 5 & Market Purchase & Mobile Telesystem OAO MTS & $\begin{array}{l}\text { Russian } \\
\text { Federation }\end{array}$ & $\begin{array}{l}\text { Russian } \\
\text { Federation }\end{array}$ & 1,530 \\
\hline 6 & $\begin{array}{l}\text { Telekomunikacja } \\
\text { Polska SA (TP SA) }\end{array}$ & $\begin{array}{l}\text { Polska Telefonia Komorkowa Centertel } \\
\text { Sp zoo (PTK Centertel) }\end{array}$ & Poland & Poland & 1,508 \\
\hline 7 & Gazprom OAO & AKS Holding OAO & $\begin{array}{l}\text { Russian } \\
\text { Federation }\end{array}$ & $\begin{array}{l}\text { Russian } \\
\text { Federation }\end{array}$ & 1,386 \\
\hline 8 & Telefonica SA & Cesky Telecom & Spain & $\begin{array}{l}\text { Czech } \\
\text { Republic }\end{array}$ & 1,077 \\
\hline 9 & Conoco Philips & LukOil & United States & $\begin{array}{l}\text { Russian } \\
\text { Federation }\end{array}$ & 1,062 \\
\hline 10 & $\begin{array}{l}\text { Raiffeisen Zentralbank } \\
\text { Oestereich AG-RZB }\end{array}$ & Aval Joint Stock Post Pension Bank & Austria & Ukraine & 1,028 \\
\hline
\end{tabular}

Whilst it is acknowledged that there is considerable variation across OECD countries using the relative ratios we may assert that many of the OECD major producing nations: US, Japan, Germany, UK, France and Italy have in terms of cross boarder capital and trade flows have significant investments in high value added industries such as bioengineering, information communication technology, pharmaceuticals and automotive technologies. Many of the firms that operate in these different market sectors are increasingly reliant on technology driven supply chains that embrace an element of physical commodities and tangible services (Botten \& McManus, 1999). The increasing importance played by technology within services industries such as banking and financial services is emphasised by the growing profits and shareholder returns even after the recent global recession of 2007-8. Within this industry information and communication, technology now enables people to participate in a growing number of service-related activities in real, or deferred, time, without having to be physically present. Within many global and international service markets the convergence of e-commerce (and business-to-business) based on internet-standards is causing a fundamental shift in the way business operates by creating new markets and new market opportunities and as a result, we are now living in a world where global-scale service companies exist for the first time (Fruin, 2009). In other words, the digital age has helped to reduce the transactions costs to a significant extent by reducing the time and effort to search for information.

As markets change so does the relationship between firms and consumers in ways that may have significant implications especially for new and emerging economies. Not only does technology allow providers to produce a single product, which is not necessarily mass-produced, it also allows a single product that is capable of being mass-consumed, either on a standardised or customised basis. For example, the software services industry has experienced exponential growth on the back of multi-media and home entertainment. As a consequence of economic liberalisation, many of the markets that were once the domain of very powerful countries such as US, Japan and Germany have become more accessible. Free trade has become a reality within the major trading blocks of EU, NAFTA, ASEN and Mercosur. Low wage inflation and access to skilled labour from Eastern Europe and OECD countries such as Turkey and Poland are enabling countries like the UK to gain stronger competitive positions in many service related industries such as call centres and other internet service provision. Those countries with low wage rates especially Mexico, Indonesia, Nigeria and Turkey (MINT) are poised to become major competitors in the next twenty years, thus, one could assume that the economic centre of gravity is not merely shifting towards these new developing countries, but may lie directly in the middle of what we currently regard as the developing MINT countries. Nations led by Mexico (who incidentally is a major producer and exporter of oil) have the capacity to become significant economic and market leaders in those moderately regulated markets where price is a key differentiator. To sum up, barriers to trade and investment in, among countries, and within markets will continue to decline in the next decade fuelling further globalisation. 


\subsection{Market Policy and Regulation}

The market and competitive forces that shape international and global business are in many respects tied paradoxically to domestic policy and regulation. Traditionally, regulation has been designed to deal with perceived market failures, such as externalities related to investment in networks or infrastructure, or asymmetric information between producers and consumers (Akerlof, 1970) for an original discussion on adverse selection and moral hazard). Studies conducted in Germany by Mannheim Innovation Panel, (1999) highlight that inappropriate regulation makes firms less likely to innovate and to adapt the quality and mix of goods and services to changing consumer needs. In recognition of the potentially adverse effects that regulation can have on markets, many of the multinational firms that operate within the OECD (and other countries such as China and India) have devised strategies and business practices that enable cross border transactions to take place under conditions that minimise bureaucracy and bureaucratic interventions. The increasing cross border transactions, inter-dependence of trade flows, investment, technology and capital creates the need for greater coordination and integration of policies relating to them. The main challenge in this context remains to effectively reduce the regulatory burden, bureaucracy across OECD as competition develops, and convergence fundamentally changes the market place. In particular, this allows a clear discussion to emerge on the global nature of firms and the role of the OECD as a prime mover in world trade and capital flows.

It could be argued that markets stand apart from much of the human institutional landscape because they were not designed by any one. In general, terms, markets are natural orders which pursue no hierarchy of ends; that is, markets do not value certain ends over other ends like the state does. In this respect markets are a mass of different perceptions and circumstances, a subtle web of individuals, or interconnecting firms as agents of individuals, trying to guess tomorrow's opportunities and customer needs. The primary function of any market is to allocate resources on the basis of price (and price alone). The rationing feature of markets originate because households tended to be relatively "self-sufficient" in the historical past with any surplus of clothing, food or drink exchanged for other commodities or early forms of money. Hence, the famous quote by Williamson: "In the beginning there were markets..." since there was little if any necessity for firms to exist. As human tastes and wants became more sophisticated, varied and precise, then firms emerged to fulfil this demand by supplying specialised goods and services.

\section{Conclusion}

The role played by the OECD in orientating market growth seems destined to grow in the near future. The evolving nature of global markets and the role of cooperation and competition in the growth process will be core elements of the way we look at economies in the future. The OECD's contribution to open markets and trade and investment liberalisation will remain a key issue in this field. In the context of the author's discussion, both global cooperation and national competitiveness have been considered by assessing recent developments in countries belonging to the OECD and those of the emerging economies. The role of markets and firms has been assessed in terms of a broadly Transaction Cost approach. It is argued that reconstructing markets more purposefully in a global twenty first Century economy requires considerable motivation on the part of OECD national governments as well as businesses in order to work together in partnerships rather than exclusively competitively. This could be achieved through a number of policy initiatives based on Free Trade using trading blocs like the European Union and North American Free Trade Agreement (NAFTA) as a conduit for accountable and transparent transactions. In turn, this could use a broader commissioning strategy to reduce costs, increase variety and exploit specialisation at a microeconomic level. Not only would this help to reform capital structures and markets but it could furthermore allow the new emerging economies to flourish and deliver efficient outcomes to the mutual benefit of producers and consumers alike.

\section{References}

AE \& AT. (2001). Embraer joins the knowledge revolution. Aircraft Engineering and Aerospace Technology, 73(1). http://dx.doi.org/10.1108/aeat.2001.12773aab.034

Akerlof, G. A. (1970). The market for lemons: Quality uncertainty and the market mechanism. Quarterly Journal of Economics, 84, 488-500. http://dx.doi.org/10.2307/1879431

Alexis, J., \& Pench, R. L. R. (1997). Europe Competing in the Global Economy. Reports of the Competitiveness Advisory Group, Cheltenham, Edward Elgar.

Botten, N., \& McManus, J. (1999). Competitive Strategies for Service Organisations. UK: Macmillan Press.

Cowden, B., \& Alhorr, H. S. (2013). Disruptive innovation in multinational enterprises. Multinational Business Review, 21(4), 358-337. http://dx.doi.org/10.1108/MBR-05-2013-0027 
Dixit, A. K., \& Stiglitz, J. E. (1975). Monopolistic Competition and Optimum Product Diversity. Paper no. 64. University Warwick, England.

Floyd, D., \& McManus, J. (2009). To what extent has the process of globalisation reduced the national growth process in Europe? International Journal of Emerging Markets, 4(4), 335-340. http://dx.doi.org/10.1108/17468800910991232

Fruin, W. (2009). Globalization and Alfred D. Chandler's modern (American) firm: An essay. Journal of Management History, 15(3), 261-271. http://dx.doi.org/10.1108/17511340910964126

Haluk, R., \& Demirkan, D. (2012). Road mapping the next wave of sustainable IT. Foresight, 14(2), 121-138. http://dx.doi.org/10.1108/14636681211222401

Hatzichronoglou, T. (1996). Globalisation and competitiveness: Relevant indicators. Published by OECD in Paris

Hsuan J. R., \& Mahnke, V. (2011). Outsourcing R\&D: A review, model and research agenda. R\&D Management, 41(1), 1-7. http://onlinelibrary.wiley.com/doi/10.1111/j.1467-9310.2010.00627.x/pdf

Krugman, P. (2016). Brazil's economy resilient to global risk. Retrieved January 14, 2016 from http://news.xinhuanet.com/english/business/2014-03/19/c_133197208.htm

McManus, J., \& Botten, N. (2006). Competitive Analysis: Thinking beyond stage one. Management Services, 50(2), 10-15.

McManus, J., Li, M., \& Moitra, D. (2007). China and India: Opportunities and Threats for the Global Software Industry. UK: Elsevier.

McManus, J., White, D., \& Botten, N. (2009). Strategy: Rethinking the paradigm. Strategic Direction, 25(9). http://dx.doi.org/10.1108/sd.2009.05625iad.007

Ohmae, K. (1995). The End of the Nation-State: The Rise of Regional Economies. New York: Simon and Schuster Inc.

Peaucelle, J. L. (2000). From Taylorism to post - Taylorism: Simultaneously pursuing several management objectives. Journal of Organizational Change Management, 13(5), 452-467. http://dx.doi.org/10.1108/09534810010377426

Porter, M. E. (1998). The Competitive Advantage of Nations (2nd ed.). New York: Free Press.

Price Waterhouse Coopers. (2005). 'Escalating deals', Price Waterhouse Coopers. Retrieved January 14, 2016, from http://www.pwc.com/mandace

Robinson, W., \& Harris, J. (2000). Towards a Global Ruling Class? Globalization and the Transnational Capitalist Class. Science \& Society, 64(1), 11-54. http://www.jstor.org/stable/40403824

Rudall, B. H. (2004) Innovative systems. $\quad$ Kybernetes, $33(1), \quad 8-21$. http://dx.doi.org/10.1108/03684920410514292

Schott, P. K. (2007). The relative sophistication of Chinese exports. NBER Working Paper No. 12173. Cambridge, MA: National Bureau of Economic Research.

Shapiro, C., \& Varian, H. (1999). Information Rules: A Strategic Guide to the Network Economy. USA: Harvard Business School Press.

Stalk, G., \& Hout, T. (1990). Competing against Time. New York: Free Press.

Stiglitz, J. E., (2010). The Stiglitz Report: Reforming the International Monetary and Financial Systems in the Wake of the Global Crisis. New York: New Press.

Tomlinson, P. R., \& Jackson, I. (2013). Co-operative ties and the impact of external factors upon innovation in an industrial district: Some insights from the North Staffordshire Table and Giftware sector. Regional Studies, 47(4), 580-596. http://dx.doi.org/10.1080/00343404.2011.585148

Williamson, O. E. (1975). Markets and Hierarchies: Analysis and Anti-trust Implications: A Study in the Economics of Internal Organization. New York: Free Press.

Williamson, O. E. (1985). The Economic Institutions of Capitalism. New York: Free Press.

Zoellick, R. B. (2010). The end of the third world? Modernizing multilateralism for a multipolar world. Washington, DC: World Bank. 


\section{Copyrights}

Copyright for this article is retained by the author(s), with first publication rights granted to the journal.

This is an open-access article distributed under the terms and conditions of the Creative Commons Attribution license (http://creativecommons.org/licenses/by/4.0/). 